\title{
Project Management for Cultural and Creative Goods
}

\author{
Liya Lin \\ Department of Film and TV \\ Fuzhou University of International Studies and Trade \\ Fujian, China
}

\author{
Guochao Lin \\ Department of Business Administration \\ Fuzhou University of International Studies and Trade \\ Fujian, China
}

\begin{abstract}
This paper aims to use Project Management techniques to explore the feasibility of the marketing of Cultural and Creative Goods. According to the five steps of project management theory, they are start, planning, execution and control to the end. In practice the combination of case execution with the situation analysis, strategic planning, value creation, product sales, customer service of marketing management, one by one to expand the planning, implementation and control, to the end of the project. The result of study is to assess the performance of marketing project and review the implementation processes to figure out the defects, also provide with proposed recommendations for cultural and creative managers to improve the implementation of marketing program for Cultural and Creative Goods.
\end{abstract}

Keywords—project management; cultural and creative goods

\section{INTRODUCTION}

In the evolution of the knowledge economy, after high-tech economy, culture creative industry has become the most profitable industry in soft power economy. It has promoted by countries around the world, including the both sides of the Taiwan Straits. Laws and policies are issued by governments to support the development of business, for instance, developing culture and creative industry was one of the main decisions in China's "Twelfth Five-year Plan" and the Development Law of Culture and Creative Industry was also issued by Taiwan at the same time. Both of them give the development direction of entrepreneurship and enforcement rules. However, the most important thing of these decisions is to focus on execution and implementation. Under the cooperation of Fujian Province and Taiwan, how to create new value in the design of cultural and creative product in pilot project? Which business model should be selected in the integrated international markets? How to design the culture products between Fujian and Taiwan by using their education, arts and technology resources? These questions are the motivations of this study. In order to find the feasibility of culture creative industry, project management technique, culture and creative industry project marketing are used in this research. Research method is followed by the project management theory which includes five steps: starting, planning, implementing, controlling and the end. In terms of pragmatic practice, the practical situation analysis, strategy formulation, value creation, product sales, customer service of marketing management are used which are also followed by the five steps. Finally, the feasibility of project marketing and project management will be evaluated and discussed.

\section{PROJECT PLANNING}

This is a two-year project. Planning the development of creative design and value creation platform is the objective of this project. It gives consideration to both sides of value creation and value realization. The scope of the project refers to six areas of cultural creative industry, including designing industry, processing industry, digital entertainment industry, popular show performing industry, visual arts industry, and design brand fashion industry. Project management process is divided into five stages: starting, planning, implementing, controlling and the end. The project authorization was firstly drafted by project sponsor, and then the content of authorization letter was discussed by project manager and team members. After that, the project plan was developed by project manager and team members and then the project plan was approved by project sponsor and distributed it to the related stakeholders. The plan was implemented by the project team and achievements were produced on a regular basis. Finally, the project should be ended by the approval of customers and the data should be collected, sorted and retained to distribute to the related stakeholders. The details are shown in "TableI".

\section{A. Marketing Project Management Matrix}

Golden orchid, one of the culture and creative product, cast work connotation and create value. It contains initial stage of excavating the original knowledge of culture characteristic and the choosing cultural creative industry projects, the planning stage of designing feasibility evaluation plan and establishing a creative workshop and information zed platform business model, the implementing stage of generating ideas, value, knowledge, patent, technology transformation, authorization and product marketing, the controlling stage of results evaluating and analyzing, intellectual property and intellectual capital and the final stage of the project completion and customer service. The marketing project management matrix is shown in "Table I" below. 
TABLE I. MARKETING ProjeCt MANAGEMENT MATRIX

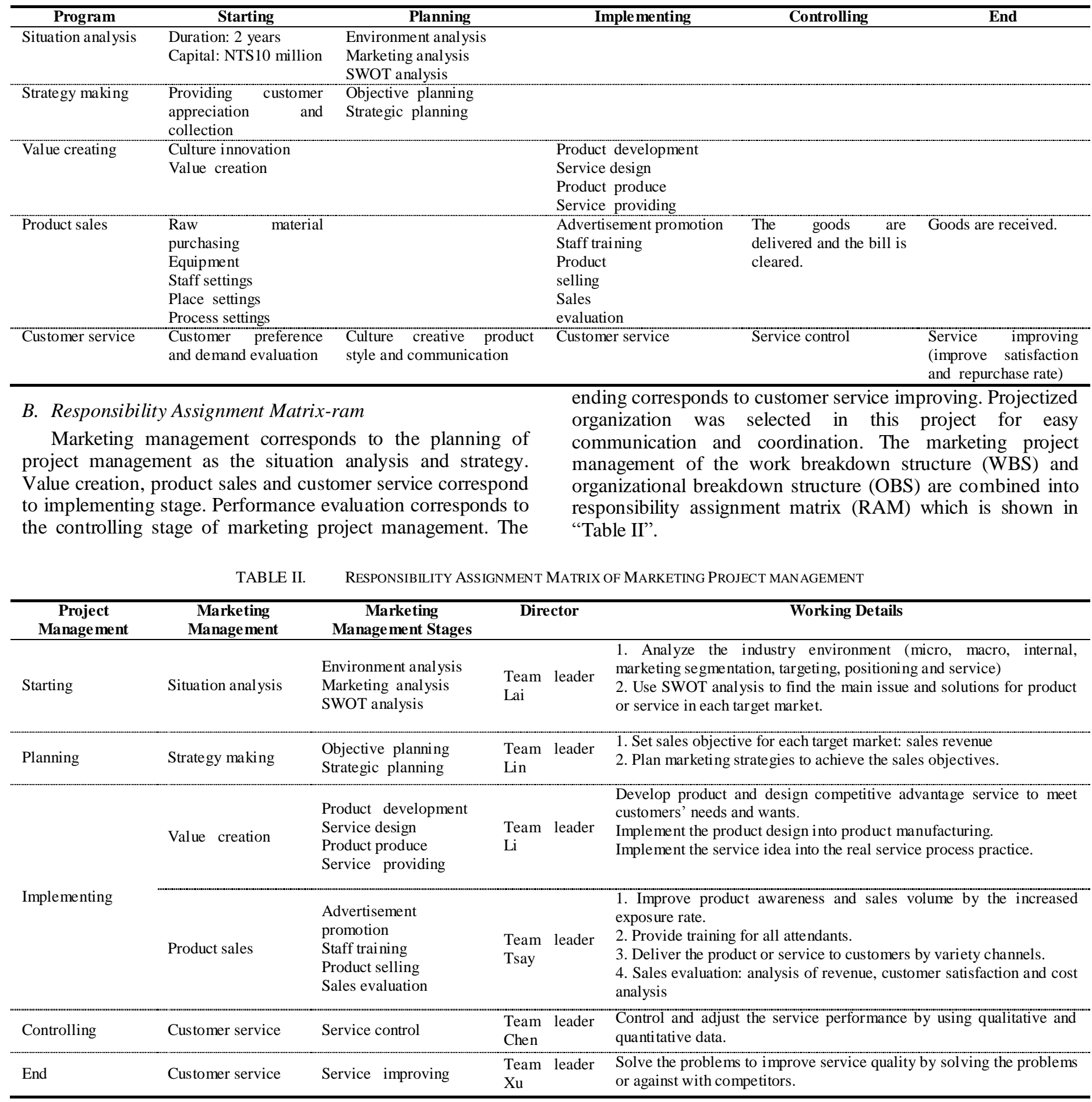

\section{Resources Requirement}

The resources requirements of this project include staff training for marketing promotion and market analysis, marketing research, interview, advocacy, Print media, Emarketing, salaries for charity activity staff. The total financial budget is about NTS 4.5 million.

\section{MARKETING PROJECT IMPLEMENTATION AND CONTROL}

\section{A. Project Implementation}

The three tasks of this marketing project implementation are value creation, product sales and customer service.

1) Value creation: Creative industry value chain is taking customer-value-creation as a point of view. It divided the 
industry and academic activities into different sessions and defined as creative industry value chain. This value chain developed the function of creative add-value in every stage of the industry. Take creative goods, orchid, as example. Orchid, as a biotechnology flower, is known all over the world. How to continue its vitality and bring more value and add-value are becoming the theme of cross field research and development. Value creation includes product development, service design, product manufacturing, service setting and logistic distribution. There are five stages for value creation of this project:

- Product innovation: Invest production materials or raw materials processing activities, especially the local culture investment.

- Creative Design: The value of innovation knowledge will integrated the value of other industries. In this process, intellectual property rights, patent right and other intellectual capital, such as physical commodity intangible service, information or applied art or invisible acting performances will be produced.

- Creative Producing and Packaging: It is a transferring activity which changes the raw material elements into final products, including producing, designing, promotion and packaging, assembling and testing, and customer activities.

- Creative Marketing and Value-added marketing: Make sure customer not only can know the products but also can facilitate the purchase behavior, including advertisement and promotion.

- Creative Service add-value: It can preserve or strengthen the relevant activities of the products' value, including fixing and install.

2) Product sales: Product sales are divided into advertising, training, products/service selling and sales elevation. It is through the way of increased exposure rate to improve their products awareness and product sale. It provides the education training to the people who take apart in the activity and delivers the products or services to consumers by various channels. Finally, sales evaluation for the analysis of revenue, customer satisfaction and cost are provided. Promotion activities of advertising based on the way of logging into the websites such as Kimo, PC home, MSN and so on to make the surfer to search the websites more quickly. Publishing the advertisements on the main website can lead the visitors to the target sites in a minute. Topic marketing is implemented by the relate topic to stimulate the surfers to click on the contents. Keyword marketing is convenient for costumers to search the information by keywords. Personal training includes the train on counter selling, network selling, production professional, inspection and equipment repair and so on. Marketing performance evaluation is for the inspection of culture creative activities, developing talent and creating commodity output for cultural creative products.
3) Customer service: Customer service is the process to provide service, including service preparing, during the service and after service. Service preparing is important because it is the period to understand the customers' needs and wants, provide related answers to eliminate customers' uncertainty and check and collate the sales data and comments to provide further services.

\section{B. Marketing Project Control}

Service control is the process of controlling and adjusting for service performance. This project focused on the creative element and creates new value by value-created operation model. The control and evaluation of service performance are the support evidence for the further improvements. The qualitative and quantitative guideposts are shown in "Table III".

TABLE III. ThE QuALITATIVE AND QuANTITATIVE GuIdEPOSTS OF MARKETING PROJECT

\begin{tabular}{ll}
\hline \multicolumn{1}{c}{ Guideposts } & \multicolumn{1}{c}{ Evaluation Contents } \\
\hline Qualitative & $\begin{array}{l}\text { 1. Check the current technical route and industries } \\
\text { cooperation } \\
\text { 2. Improve the product add-value efficiently } \\
\text { 3. Promote the results to be commercialized } \\
\text { 4. Industry communication plan }\end{array}$ \\
\hline Quantitative & $\begin{array}{l}\text { 1. The person-time of culture creative talents training } \\
\text { 2. Sessions of holding culture creative activities } \\
\text { 3. The number of university-industry collaboration } \\
\text { 4. The number of creative products commercialized } \\
\text { 5. The number of creative theme innovated } \\
\text { 6. The number of international events planed }\end{array}$ \\
\hline
\end{tabular}

\section{THE END OF MARKETING PROJECT}

Customer service improvement is to solve the existing problems to improve service quality or to update service level to against with competitors. This process includes customer complaints management, customer satisfaction research, dissatisfaction aspects improvement, and service process improvement or redesign and service process innovation.

\section{THE ACHIEVEMENTS OF MARKETING PROJECT IMPLEMENTATION}

In terms of qualitative guidepost, the marketing project implementation invited the excellent scholars in design industry to give lessons or training and invested theme working office. Discussions of university-industry collaboration, academic exchange, technology exchange are also provided. Base on these interdisciplinary activities, the diversified talents of culture creation are trained. In terms of quantitative guidepost, achievements are reflected in number of culture creative talents training, culture creative activities, university-industry collaboration, creative products commercialization, creative theme innovation and international events. The details are shown in "Table IV". 
TABLE IV. The Performance of Marketing Project IMPLEMENTATION

\begin{tabular}{|c|c|c|c|c|}
\hline Guidepost & Evaluated Items & 2011 & 2012 & Increase \\
\hline \multirow{5}{*}{$\begin{array}{l}\text { Culture } \\
\text { creative } \\
\text { talents } \\
\text { training }\end{array}$} & The number of talents & 58 & 73 & $25.9 \%$ \\
\hline & $\begin{array}{l}\text { The number of university } \\
\text { designer } \\
\text { program }\end{array}$ & 8 & 10 & $25.0 \%$ \\
\hline & $\begin{array}{l}\text { The number of certified } \\
\text { university designer }\end{array}$ & 66 & 93 & $40.9 \%$ \\
\hline & $\begin{array}{l}\text { The number of outside } \\
\text { school designer } \\
\text { participants }\end{array}$ & 13 & 17 & $30.8 \%$ \\
\hline & $\begin{array}{l}\text { The number of talent } \\
\text { graduates }\end{array}$ & 8 & 9 & $12.5 \%$ \\
\hline \multirow{2}{*}{$\begin{array}{l}\text { Culture } \\
\text { creative } \\
\text { activities }\end{array}$} & $\begin{array}{l}\text { The number of creative } \\
\text { competition }\end{array}$ & 3 & 7 & $133.3 \%$ \\
\hline & $\begin{array}{l}\text { The number of } \\
\text { interdisciplinary } \\
\text { discussion activities }\end{array}$ & 4 & 5 & $25.0 \%$ \\
\hline \multirow{2}{*}{$\begin{array}{l}\text { University- } \\
\text { industry } \\
\text { collaboratio } \\
n\end{array}$} & $\begin{array}{l}\text { The number of contracts } \\
\text { with companies }\end{array}$ & 5 & 7 & $40.0 \%$ \\
\hline & $\begin{array}{l}\text { The number of cases } \\
\text { with university-industry } \\
\text { collaboration }\end{array}$ & 3 & 4 & $33.3 \%$ \\
\hline $\begin{array}{l}\text { Commercial } \\
\text { ization }\end{array}$ & $\begin{array}{l}\text { The number of creative } \\
\text { products commercialized }\end{array}$ & 10 & 13 & $30.0 \%$ \\
\hline $\begin{array}{l}\text { creative } \\
\text { theme } \\
\text { innovation }\end{array}$ & $\begin{array}{l}\text { The number of creative } \\
\text { theme innovated }\end{array}$ & 13 & 15 & $15.4 \%$ \\
\hline $\begin{array}{l}\text { Event } \\
\text { planning }\end{array}$ & $\begin{array}{l}\text { The number of } \\
\text { international events } \\
\text { planed }\end{array}$ & 1 & 1 & $0.0 \%$ \\
\hline
\end{tabular}

\section{DISCUSSION AND RECOMMENDATIONS}

Chinese Premier Wen Jiabao treated cultural construction and cultural innovation as development emphasis in the Government Work Report 2010. Likewise, Taiwan Executive Yuan also introduced a number of relevant policies. Firstly, they announced Cultural Creative Industry as one of the six important emerging industries in 2009 and then Legislative Yuan issued the Law of Cultural Creative Industry Development in 2010. It was considered that the cultural creative industry is a booming industry and the commercial opportunities within this industry will be realized. The results of this research indicate that the marketing project makes great achievement in cultural creative talents training. The number of creative products commercialized increased $30 \%$ and the number of creative competitions increased $133.3 \%$, which shows that this marketing project is worth generalizing. Nevertheless, it was found that the most important thing is to service customers by creating the value of customers in the marketing project of cultural creative industry. Therefore, only when professionals constantly apply for in-service training for progress in professional skills can their creative products win the favor of customers. Besides, lasting being excellent in service process is needed because it will build good reputation when customers think the quality is beyond the price.

\section{REFERENCES}

[1] IPMA Level C, Knowledge System of International Marketing Project Management, (2009), Taiwan Project Management Association.
[2] IPMA Level C, Project Report: Special Interview Casebook, (2013), Taiwan Project Management Association.

[3] IPMA Level D, Knowledge System of International Project Management, (2009), Taiwan Project Management Association. 